\title{
Frontal lobe metastases as the initial presentation of follicular thyroid carcinoma
}

\author{
Metástasis en el lóbulo frontal como primera manifestación clínica de un carcinoma \\ folicular de tiroides \\ Delia Luján-Martínez*, Miguel Ruiz-Marín, Emilio Peña-Ros, Antonio Albarracín-Marín-Blázquez and \\ Marifé Candel-Arenas \\ Department of General Surgery and Digestive Diseases, Hospital General Universitario Reina Sofía, Murcia, Spain
}

\begin{abstract}
Background: Follicular thyroid carcinoma can produce distant metastases, generally occur to lung followed by bone. Brain metastases are unusual, and onset manifestation is little frequently. Clinical case: A 80-years old men presented disturbance behavior, disorientation and loss of sphincters after falling to the ground. Computed tomography scan showed a lesion in the right frontal lobe. The patient underwent a craniotomy to remove the brain tumor, histopathology confirmed of follicular thyroid carcinoma metastases. Conclusion: At initial diagnosis brain metastasis are extremely rare, with adverse prognosis.
\end{abstract}

Key words: Brain metastases. Follicular thyroid carcinoma. Thyroid carcinoma.

\section{Resumen}

Antecedentes: El carcinoma folicular de tiroides puede producir metástasis a distancia, siendo las localizaciones más habituales el pulmón y el hueso. Las metástasis cerebrales son inusuales, y es poco habitual que aparezcan como primera manifestación de cáncer. Caso clínico: Paciente varón de 80 años, que tras una caída al suelo comenzó con alteración del comportamiento, desorientación y pérdida del control de esfínteres. La tomografía computarizada cerebral evidenció una masa en el lóbulo frontal derecho. Se realizó la extirpación de la lesión cerebral, cuyo estudio histológico informó de metástasis de carcinoma folicular de tiroides. Conclusión: La manifestación de la enfermedad con metástasis cerebrales es muy infrecuente, y empeora el pronóstico notablemente.

Palabras clave: Metástasis cerebral. Carcinoma folicular de tiroides. Carcinoma de tiroides.

\section{Background}

Differentiated thyroid carcinoma (DTC), including papillary carcinoma (PC) and follicular carcinoma (FC), is associated with a favorable prognosis, with a 10 -year survival of $80-90 \%$. However, although these neoplasms are very similar, they have a different behavior. PC metastasizes more often to regional lymph nodes, and in no few occasions, cervical adenopathies are the first symptom 1 . FC is more vascularized and, therefore, it produces distant metastases more frequently than $\mathrm{PC}$, with most usual locations being 
the lung and bone, but the appearance of these as the first manifestation is unusual. DTC brain metastases (BM) are unusual and most are diagnosed during primary tumor follow-up².

The presence of BM worsens the prognosis, since it is considered as a terminal stage of the disease'.

We present a case of thyroid FC that had brain metastasis to the front lobe as first manifestation.

\section{Clinical case}

80-year-old male, with no prior history data of interest except for left ear intervention and femoral fracture. After a fall to the ground he started experiencing behavioral alteration, disorientation and loss of sphincter control. Neurological examination was normal and on brain computed tomography (Fig. 1), a $29 \times 26 \times$ $30 \mathrm{~mm}$ mass was observed at the right frontal lobe, with intense, heterogeneous enhancement after contrast administration, necrotic central areas and adjacent density extensive alteration due to hypodensity of digitiform morphology in frontal white matter and corpus callosum knee, with mass effect on the ventricular system. Magnetic resonance imaging (Fig. 2) showed poorly-defined contours in the posterior and inferior margins of the lesion, with extensive alteration of the signal in adjacent white matter, of digitiform morphology, which caused an important mass effect on the grooves and the ventricular system, with compression of the frontal horn and right ventricle body, and signs of subfalcine herniation.

With the diagnosis of high-grade primary tumor or single metastasis, the patient was surgically intervened and complete removal of the brain lesion was carried out, with histological examination reporting thyroid FC metastasis (Fig. 3).

Cervical ultrasound (Fig. 4) and computed tomography were showed a bulky mass in the left thyroid lobe with calcifications and intrathoracic extension, with an approximate size of $5 \times 3.5 \mathrm{~cm}$, which contacted the left jugular vein, deforming it, with no adenopathies being observed. Multiple pulmonary micronodules were also found, in the upper lobes, which were consistent with metastasis. Fine needle puncture-aspiration of the nodule was performed, which reported FC suspicion. Laboratory tests showed normal thyroid function and very high thyroglobulin $(600.8 \mathrm{ng} / \mathrm{mL})$.

Cervical surgery was carried out, and total bilateral thyroidectomy was decided when a hard and whitish nodule, of more than $5 \mathrm{~cm}$, was found in the left thyroid lobe. Postoperative period was uneventful.

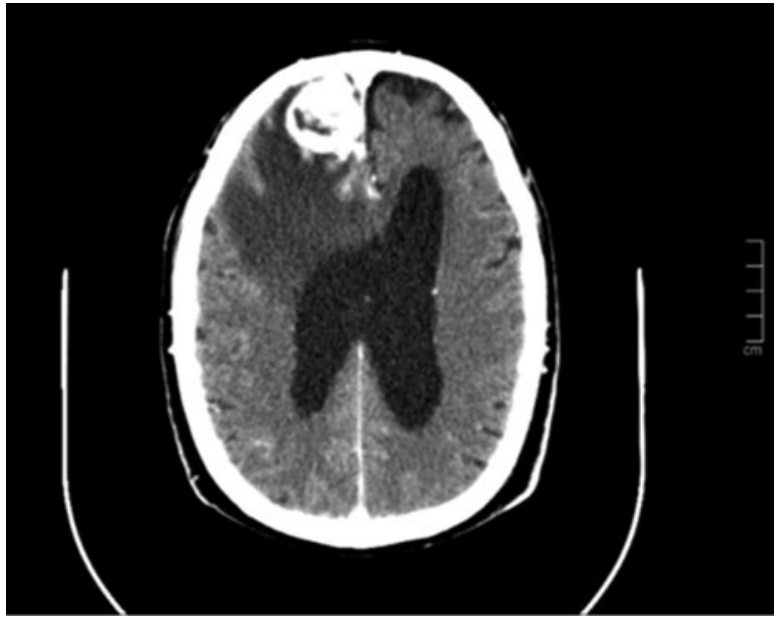

Figure 1. Brain CT scan showing a $29 \times 26 \times 30 \mathrm{~mm}$ lesion in the right frontal lobe, with intense heterogeneous enhancement after contrast administration, central necrotic areas and extensive alteration of adjacent density due to hypodensity of digitiform morphology in frontal white matter and corpus callosum knee, with mass effect on the ventricular system.


Figure 2. Brain magnetic resonance imaging. A: T1-weighted sagittal section showing a right frontal mass located on the right upper front gyrus, centered on the corticosubcortical junction. B: T2-weighted axial section where a signal alteration of adjacent white matter is observed, which favors an important mass effect on the grooves and the ventricular system, and subfalcine herniation with $8.5-\mathrm{mm}$ shift from midline.



Figure 3. Histological findings of brain parenchyma invasion (black star) by follicular cells (circle). 




Figure 4. Cervical ultrasound showing a heterogeneous lesion in left thyroid lobe with calcifications within.

Definitive pathological anatomy confirmed the thyroid FC diagnosis. Currently, the patient is waiting to receive radioiodine.

\section{Discussion}

BMs appear in $20-30 \%$ of patients with cancer. However, in DTCs, they occur in less than $2 \%$ of cases $^{1}$. They are especially observed in elderly male patients, with primary tumors of large size and aggressive histological variety ${ }^{1-3}$, and it is unusual for them to be the first manifestation of the disease. The most common localization is in the cerebral hemispheres ${ }^{4}$, as it occurred in our case, although they can also appear in the cerebellum and pituitary.

Clinically, they can cause headache, motor weakness, visual loss and seizures, and can even be asymptomatic ${ }^{5}$. Most are diagnosed by means of imaging techniques, with the ones with the highest performance being $\mathrm{MRI}$ and computerized tomography. They can also be diagnosed when visualizing brain uptake when performing a scan after treatment with ${ }^{131}$. Average interval between DTC diagnosis and BM identification is 2.9 years $^{6}$.

The presence of synchronous lung metastases is often common at diagnosis ${ }^{2,3}$, although these are not a significant predictive factor. Patients with BM tend to have lung metastases when they are diagnosed, as our patient.

Serum thyroglobulin concentrations are used to detect distant metastases during the follow-up of patients intervened for DTC ${ }^{1}$. Thyroglobulin is a tumor marker that drops after applying an appropriate treatment, and if values remain high, this could indicate early disease relapse ${ }^{6}$. Thyroglobulin values are related to overall survival ${ }^{5}$. In our case, high values were observed already at diagnosis ${ }^{1,5,6}$.

DTC BMs clinical course of is not well established due to their low prevalence. Retrospective studies ${ }^{2,3}$ assess prognostic factors of survival and conclude that age ( $\leq 60$ years), having less than three intracranial lesions and absence of distant metastases prior to the development of BM are independently associated with survival. With regard to these data, we are in favor, whenever possible, of carrying out BMs definitive treatment in order to improve survival.

The treatment of choice consists of BM resection surgery followed by radiotherapy ${ }^{3,6,7}$. Radiotherapy should also be considered in patients who cannot undergo surgery and in case of multiple metastases ${ }^{6}$. Primary tumor complete resection associated with radioiodine treatment is essential $\left.\right|^{8,9}$. In our case, FC diagnosis was established after BM removal. Other studies $^{10}$ suggest that all these therapeutic measures do not improve patient survival due to advanced systemic disease, but provide better local control of the metastatic brain tumor.

In general, it is accepted that patients with BM from a DTC have a longer survival than that of those with BM from other solid tumors ${ }^{1}$. To avoid relapses, it is essential that FC initial treatment is complete. Furthermore, we consider that once BMs are diagnosed, both on follow-up and if they are the first manifestation, complete resection followed by radiotherapy is essential in order to prolong survival.

\section{Ethical disclosure}

Protection of people and animals. The authors declare that no experiments were performed on humans or animals for this investigation.

Confidentiality of data. The authors declare that they have followed the protocols of their work center on the publication of patient data.

Right to privacy and informed consent. The authors declare that no patient data appear in this article.

\section{Conflict of interests}

The authors declare that there are no conflicts of interests.

\section{Funding}

The authors declare that there is no external funding. 


\section{Luján Martínez, et al.: Frontal lobe metastases}

\section{References}

1. Lee HS, Yoo H, Lee SH, Gwak HS, Shin SH. Clinical characteristics and follow-up of intracranial metastases from thyroid cancer. Acta Neurochir. 2015;157:2185-94.

2. Saito F, Uruno T, Shibuya H, Kitagawa W, Nagahama M, Sugino K, et al Prognosis after brain metastasis from differentiated thyroid carcinoma. World J Surg. 2016;40:574-81.

3. Choi J, Kim JW, Keum YS, Lee IJ. The largest known survival analysis of patients with brain metastasis from thyroid cancer base on prognostic groups. PLoS One. 2016;11:e0154739.

4. Pazaitou-Panayioutu K, Kaprara A, Chrisoulidou A, Boudina M Georgiou E, Patakiouta F, et al. Cerebellar metastasis as first metastasis on papillary thyroid carcinoma. Endocr J. 2005;52:653-7.

5. Cacho-Díaz B, Spínola-Maroño H, Granados-García M, Reyes-Soto G Cuevas-Ramos D, Herrera-Gómez A, et al. Metástasis cerebrales en pacientes con cáncer de tiroides. Med Int Mex. 2017;33:428-8.
6. Han E, Lee YY, Kim E, Kwon SY, Kim SP, Kim HS, et al. Solitary bone and brain metastasis in patient with papillary thyroid carcinoma mimicking cavernous angioma. Korean J Intern Med. 2016;31:991-4.

7. Ríos A, Galindo PJ, Rodríguez J, Tebar FJ, Parrilla P. Metástasis cerebral por un carcinoma folicular de tiroides. Tratamiento inicial inadecuado como factor pronóstico. Endocrinol Nutr. 2009;56:99-101.

8. Vrachimis A, Schmid KW, Jurgens $H$, Schober O, Weckesser M, Riemann B. Cerebral metastases from thyroid carcinoma: complete remission following radioiodine treatment. Dtsch Arztebl Int. 2013; 110:861-6.

9. Durante C, Haddy N, Baudin E, Leboulleux S, Hartl D, Travagli JP, et al. Longterm outcome of 444 patients with distant metastases from papillary and follicular thyroid carcinoma: benefits and limits of radioiodine therapy. J Clin Endocrinol Metab. 2006;91:2892-9.

10. Tsuda K, Tsurushima H, Takano S, Tsuboi K, Matsumura A. Brain metastasis from papillary thyroid carcinomas. Mol Clin Oncol. 2013;1:817-9. 